\title{
SUBCONTRACTOR SELECTION PRACTICES IN INTERNATIONAL CONSTRUCTION PROJECTS
}

\author{
Serdar Ulubeyli ${ }^{1}$, Ekrem Manisali ${ }^{2}$, Aynur Kazaz $^{3}$ \\ ${ }^{1}$ Civil Engineering Department, Engineering Faculty, Zonguldak Karaelmas University, 67100, Zonguldak, Turkey \\ ${ }^{2}$ Civil Engineering Department, Istanbul University, 34320 Avcilar, Istanbul, Turkey \\ ${ }^{3}$ Civil Engineering Department, Engineering Faculty, Akdeniz University, 07058 Antalya, Turkey

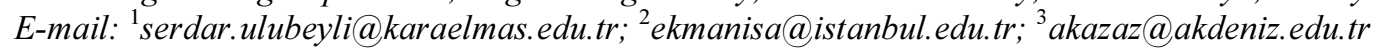 \\ Received 05 Feb. 2009; accepted 15 July 2009
}

\begin{abstract}
This paper presents a study of subcontractor selection practices of Turkish contractors in international projects. The results highlight the current subcontracting practices of main contracting firms that have resulted in a long-lasting market share abroad. Toward this aim, a detailed questionnaire was administered to 96 construction companies. Turkish and host countries' subcontractors were shown to be frequently employed in international projects. However, subcontracting firms from other countries were found to not be used. Main contracting companies generally select subcontractors in the periods after the main tender or after the project's start. Although many of them often work with previously known subcontracting companies and do not take into account the lowest bid price as the primary criterion, systematic processes or models are not used to select the best subcontractor. Most importantly, main contractors not only use subcontractors but also carry out activities using their in-house resources. Hence, this study will not only be a step for further works that can be performed by potential researchers who may find interesting similarities or differences between their countries and Turkey, but also assist contractors who plan to strengthen their positions and to increase work opportunities in the international market.
\end{abstract}

Keywords: subcontractors, selection, foreign projects, construction companies.

\section{Introduction}

Subcontracting is a widespread practice in the Turkish construction industry, as in most countries. It is estimated that there are about 20,000 subcontractors in the sector, which is twice the number of registered contractors. Unregistered firms and those known as labor-only subcontractors are not included in this figure. In other words, the construction industry in Turkey relies heavily on subcontracting as a key organizational and commercial device. However, the subcontracting system in Turkey is gradually changing. In the near term, the term 'subcontractor' has been used to describe a foreman and his crew, whose relationships are based on the relative-focused patriarchal system of the society. Today, professional companies in which a more formal worker-manager relationship is valid take part in the construction business.

In recent years, Turkish construction companies have become significantly active in the international market. In 2007, there were 22 Turkish firms among the largest 225 international contractors, and Turkey was third after the US and China, in terms of the number of firms (ENR 2008). To date, Turkish contractors have undertaken more than 4000 projects in 68 countries on four continents. Since 1972, this involvement outside of Turkey has generated $\$ 105$ billion which corresponds to approximately $1.5 \%$ of global construction revenue. In 2007 , the sum of international contracting services of
Turkish firms was $\$ 19.5$ billion for 354 projects in 34 countries. Considering the types of international projects undertaken by the members of the Turkish Contractors Association (TCA) between 1972 and 2005, residential construction was the most common type, with $23.23 \%$ of the projects. In terms of geographical dispersion, 22.99\% of the projects were completed in Libya and $20.01 \%$ in Russia (TCA 2008).

In the construction management literature, there have been only a few specific academic studies on the practice of the subcontractor selection, except for some modeling studies (Albino and Garavelli 1998; Okoroh and Torrance 1999; Kumaraswamy and Mathews 2000; Tserng and Lin 2002; Ip et al. 2004; Arslan et al. 2008). However, the present study does not offer any model framework concerning the choice of subcontractors. The cited papers above have solely concentrated on the development of the detailed subcontractor selection models and criteria rather than the introduction of some key aspects of selection matters such as subcontractor resources of main contractors, some informal attributes, the selection timing and types, subcontractor usage rates, selection guides and short-lists, and decision-makers of the subcontractor choice, as examined in this study. The application of the subcontractor selection in international construction projects has not attracted the required in-depth attention of researchers, either. Uher and Runeson (1984) investigated pre-tender and post-tender negotiations in 
Australia, but they essentially considered the bidshopping issue in the domestic market. Although Shash (1998) examined bidding practices of subcontractors in Colorado, he pinpointed the content and methods of invitation as well as bid submission, price reduction practices, and pre- and post-bid negotiations between main contractors and subcontractors in the local construction industry. Considering contractor selection models which are similar to subcontractor selection methods to some extent, there exist various articles in construction (Egemen and Mohamed 2005; Singh and Tiong 2005; Banaitienė and Banaitis 2006; Zavadskas and Vilutiene 2006; El-Sawalhi et al. 2007; Brauers et al. 2008; Turskis 2008; Zavadskas et al. 2005, 2008; Juan et al. 2009). On the other hand, the projects undertaken by main contractors are much larger scale than those of subcontractors. Furthermore, many subcontractors can be employed in a construction project under normal circumstances, while there is only one main contractor. Because of these arguments, the selection process of main contractors by clients requires following more detailed procedures and thus spending more time and effort. More importantly, these studies are far from investigating subcontracting practices. Researchers have also made numerous studies that take into account supplier or vendor selection in the manufacturing industry (DeBoer et al. 2001; Bevilacqua and Petroni 2002; Kwong et al. 2002; Dogan and Sahin 2003; Kahraman et al. 2003; Bevilacqua et al. 2006; Chang et al. 2006; Chen et al. 2006; Kagnicioglu 2006; Kumar et al. 2006; Araz et al. 2007; Chan and Kumar 2007; Haq and Kannan 2007; Isiklar et al. 2007; Lopez 2007; Wang and Che 2007; Bottani and Rizzi 2008; Chou and Chang 2008; Wang 2008). However, their core themes are directly related with the selection models that can be potentially used in the manufacturing industry in which plant-type production is in use. Even if some basic subcontractor selection criteria such as cost and quality are naturally the same to a certain extent, construction and manufacturing industries necessitate totally different conditions and application practices, specific criteria, and distinct frameworks. In other words, subcontracting as a kind of 'craft administration' of the construction contracting firm is different from 'bureaucratic administration' of the manufacturing firm (Stinchcombe 1959).

The aim of the present study is to reveal subcontractor selection practices of Turkish main contractors for the projects that they undertake abroad and to determine how the current position of subcontracting exercises influences and contributes to the main contractors' cited superior performance in foreign investments. With this purpose, certain key points such as

- Subcontracting resources,

- Some well-known and informal selection criteria,

- The time and type of the selection,

- The amount of subcontractor usage,

- Availability of a selection guide and short-list, and

- Decision-makers for subcontractor choice

are examined in detail. Consequently, this study will not only be a step for future works that can be performed by researchers who may find interesting similarities or diffe- rences between their countries and Turkey, but also assist contractors who plan to strengthen their positions and to increase work opportunities in the international market.

\section{Methodological framework}

The data presented in this study were obtained by a questionnaire survey that was given to the members of the TCA between June and August 2007 (Ulubeyli 2008). This sample group was selected because it is an accepted list of firms within the Turkish construction industry. The member firms of the TCA perform approximately $70 \%$ of the total investments made in Turkey, and they have also undertaken $90 \%$ of the work done abroad in the field of construction. There are 139 members in total, of which 96 firms $(69.06 \%)$ positively responded to the survey request. The number of companies interviewed is statistically adequate $(n \geq 30)$ to represent the whole. Furthermore, Babbie (2007) suggested that any return rate over $50 \%$ can be reported, that over $60 \%$ is good, and that over $70 \%$ is excellent. The respondents were the contractors' professional managers who choose the subcontractors. The interviews were conducted face-to-face at the interviewees' offices, and they ranged from 1 to 2 hours, with each interview being tape-recorded. The interviews were carried out in an open and semi-structured manner, allowing the respondent to introduce whatever information was felt to be relevant. In order to make the interviewing more effective and to save the time of the interviewees, the purpose of the interview and the need of the research were communicated to the interviewees before the interview through either (1) an e-mail or (2) a telephone conversation. The fact that each company's business philosophy could guide the interviewee's personal opinion was also stressed.

The survey included 26 questions, which were statistically evaluated by three different methods. The first method was the frequency technique, in which the percentage values are calculated for the frequency of each answer. The second is the 5-point Likert scale method. In the Likert scale (David and Ronald 1987), 5, 4, 3, 2, and 1 respectively represent 'always', 'usually', 'sometimes', 'rarely', and 'never'. For the analysis of this type of questions, mean values were obtained by means of equation (1):

$$
\bar{x}=\frac{\sum f x}{n}
$$

where $f$ is the frequency, $x$ denotes each value of the sample, and $n$ is the total number of samples. Standard deviation was then calculated by:

$$
s=\sqrt{\left[\frac{\sum f x^{2}}{n-1}-\frac{\left(\sum f x\right)^{2}}{n(n-1)}\right]} .
$$

The last technique employed was the 95\% confidence interval of the results (Curwin and Slater 1992). Upper and lower limits were calculated by adding and subtracting the error $(e)$ from the mean $(\bar{x})$ as in:

$$
\mu=\bar{x} \pm 1.96 \frac{s}{\sqrt{n}} \text {. }
$$


Table 1. Likert scale intervals

\begin{tabular}{ccccc}
\hline Always & Usually & Sometimes & Rarely & Never \\
\hline $4.20<\mu \leq 5.00$ & $3.40<\mu \leq 4.20$ & $2.60<\mu \leq 3.40$ & $1.80<\mu \leq 2.60$ & $1.00 \leq \mu \leq 1.80$ \\
\hline
\end{tabular}

To apply these equations, SPSS 13.0 (Statistical Package for Social Sciences) was used. However, each verbal expression in the Likert scale cannot be quantified by only one number in the evaluation phase to obtain reasonable outcomes. Thus, calculated numbers with their confidence intervals were included by one of the intervals shown in Table 1.

The demographic features of the surveyed firms, including both the respondents' characteristics and the structures of the construction companies, were revealed by the survey results. Tender Managers made up $81.25 \%$ of the participants, and $18.75 \%$ were Chairmen of the Board of Directors. The statistical data indicated that the participants had adequate business experience in the construction industry to answer the questionnaire satisfactorily. The mean $(\bar{x})$ work experience of the respondents was 17.69 years, the standard deviation $(s)$ was 10.05 years, and the median was 13.5 years. The minimum and maximum values of work experience were 7 and 36 years, respectively. In terms of respondents' working duration in their present firms, $56.25 \%$ had been working for $1-5$ years, $25 \%$ for $6-10$ years, and $18.75 \%$ for $11-20$ years. The percentage of participants who had worked for a long period of time ( $\geq 6$ years) was low $(43.75 \%$ ) due to the project-based nature of construction. In this respect, it is especially noteworthy that no participants had worked for more than 20 years in the same company. Participants were, however, knowledgeable enough to answer the questions in the name of the companies. Each participant had taken part in the selection process of at least one subcontractor, $25 \%$ had taken part in more than 50 selection processes, $18.75 \%$ had participated in fewer than 5 selections, $18.75 \%$ had been involved in $6-10$ selections, $25 \%$ had been involved in 11-20 selections, and $12.5 \%$ had taken part in $21-50$ selections. As a result, the professional background and qualifications of the respondents were found to be sufficient for the validation of the presented survey results.

Besides the individual characteristics of the respondents, the features of the surveyed firms are also very important. Considering their average annual revenues, a vast majority of companies $(81.25 \%)$ can be considered as being in the large scale ( $>\$ 20$ million) category while $6.25 \%$ of main contractors were middle scale firms $(\$ 10$ 20 million), and $12.5 \%$ were small scale firms $(<\$ 10$ million). The fact that large scale firms are likely to have high standards in terms of the internal organization and project characteristics both indicates the reliability of the survey and has led to further research projections for the future. The surveyed companies had undertaken foreign construction projects in more than one field of construction to date. According to types of international projects, $81.25 \%$ of main contractors had performed engineering projects (highways, bridges, harbours, tunnels, dams, and infrastructure). The fact that international projects are composed of engineering investments in general is an expected finding. In addition, $62.5 \%$ of the companies had executed industrial investments (power plants, refineries, and pipelines), and $62.5 \%$ had completed building projects (residential, commercial, schools, hotels, and hospitals). This indicates that main contractor firms have not specialized in only one specific project type and that subcontracting has become an inevitable tool of trade contracting for main contractors in the international construction industry. Considering the firms' business experience, $18.75 \%$ of them had been in the global construction market for $1-5$ years, $25 \%$ for $6-10$ years, $6.25 \%$ for $11-20$ years, and $50 \%$ for more than 20 years. A significant portion of main contractors $(56.25 \%)$ have been undertaking international projects for more than 10 years. This points out that they have adequate experience in foreign markets. Another indicator of the surveyed firms' international experience is the number of projects undertaken abroad. Of the firms, $18.75 \%$ had served as main contractors in $1-5$ projects, $15.62 \%$ in $6-15$ projects, $15.62 \%$ in $16-25$ projects, and $12.5 \%$ in $26-50$ projects. The fact that $37.5 \%$ of main contractors had successfully completed more than 50 foreign projects is an important finding, showing their widespread experience. Similarly, it was found that main contractors had successfully concluded many large scale foreign projects. Considering the maximum size of the labor force, $12.5 \%$ of main contractors had employed fewer than 100 workers in a project, $18.75 \%$ had employed $100-500$ workers, $25 \%$ had employed 501-1000 workers, $31.25 \%$ had employed 1001-5000 workers, and $12.5 \%$ had employed more than 5000 workers. The firms had concurrently undertaken construction projects in three different continents. The former Soviet Countries, the Middle East, and North Africa are especially vital and strategic markets for Turkish construction companies (Fig. 1). Turkish contractors are thus knowledgeable about various global subcontracting practices.

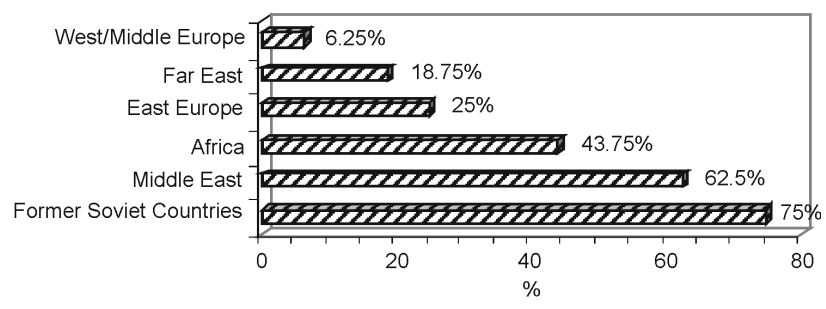

Fig. 1. Geographical dispersion of foreign projects

\section{Subcontractor choice in foreign projects}

Because of shortages of financial resources, some large scale firms supplying main contracting services in the domestic market can be hired as subcontractors in international construction projects. When Turkish contractors first entered the international construction market in the 
early 1970s, almost all of them worked as subcontractors for main contractors from developed countries. However, this has evolved over three decades in terms of both their financial and technological capacities. Parallel to this historical progress, $68.75 \%$ of the surveyed companies had worked as main contractors in foreign projects, while $31.25 \%$ had supplied main contracting and subcontracting services. This also indicates that answers to the questionnaire may reflect thoughts from both sides of this issue.

Some construction companies develop flexibility and expansion strategies, enhancing their capabilities in order to undertake projects concurrently in different geographical locations by means of subcontractors. This also prevents potential difficulties during the transportation of resources. The surveyed firms 'usually' use subcontractors in foreign projects, as shown in Table 2, and $25 \%$ of them 'always' employ subcontractors. Just $6.25 \%$ of main contractors 'never' make subcontracting agreements since they specialize in particular aspects of the construction industry.
The most specific characteristic of subcontracting practices in the industry is that the majority of main contractors are not involved in the physical construction work. Main contractors essentially undertake only the management, planning, and co-ordination activities of the project, rather than the actual production work, which is performed by subcontractors. In other words, the main contractor controls whether the work is carried out according to the required quality standards in the main contract and the related specifications. As a result, main contractors create suitable working conditions for the actual builders, and they enable these production units to make progress financially and technically in the long term. When cost-based average work amounts transferred to subcontractors in international projects are examined, only $6.25 \%$ of main contractors share their entire projects with subcontractors, as shown in Fig. 2. However, 50\% of them transfer at least $50 \%$ of the work, and the remainder is equally dispersed. Note that these amounts can change with the economic conditions of the host country and from project to project.

Table 2. Descriptive statistics

\begin{tabular}{|c|c|c|c|c|c|}
\hline \multirow{2}{*}{$\begin{array}{l}\text { Mean } \\
(\bar{x})\end{array}$} & \multirow{2}{*}{$\begin{array}{l}\text { Standard deviation } \\
(s)\end{array}$} & \multirow{2}{*}{$\begin{array}{l}\text { Error } \\
(e)\end{array}$} & \multicolumn{2}{|c|}{$95 \%$ confidence interval $(\mu)$} & \multirow{2}{*}{$\begin{array}{l}\text { Concluding } \\
\text { interval }\end{array}$} \\
\hline & & & Upper limit & Lower limit & \\
\hline \multicolumn{6}{|c|}{ Subcontractor usage in foreign projects } \\
\hline 3.75 & 1.095 & 0.219 & 3.969 & 3.531 & Usually \\
\hline \multicolumn{6}{|c|}{ Selection by competitive bidding } \\
\hline 3.5 & 1.005 & 0.181 & 3.701 & 3.299 & Usually / Sometimes \\
\hline \multicolumn{6}{|c|}{ Selecting by negotiation } \\
\hline 2.75 & 0.906 & 0.181 & 2.931 & 2.569 & Sometimes / Rarely \\
\hline \multicolumn{6}{|c|}{ Selection after the project start } \\
\hline 3.25 & 0.973 & 0.195 & 3.445 & 3.055 & Usually / Sometimes \\
\hline \multicolumn{6}{|c|}{ Selection between the main tender and the project start } \\
\hline 3 & 0.562 & 0.112 & 3.112 & 2.888 & Sometimes \\
\hline \multicolumn{6}{|c|}{ Selection before the main tender } \\
\hline 2.94 & 0.904 & 0.181 & 3.121 & 2.759 & Sometimes \\
\hline \multicolumn{6}{|c|}{ Selection based on bidding price } \\
\hline 3 & 0.562 & 0.112 & 3.112 & 2.888 & Sometimes \\
\hline \multicolumn{6}{|c|}{ Selection based on the lowest bid } \\
\hline 2.56 & 1.064 & 0.213 & 2.773 & 2.347 & Sometimes / Rarely \\
\hline \multicolumn{6}{|c|}{ Selection based on decision-maker's experience } \\
\hline 3.31 & 1.268 & 0.254 & 3.564 & 3.056 & Usually / Sometimes \\
\hline \multicolumn{6}{|c|}{ Selection based on previous working relationship } \\
\hline 3.75 & 0.665 & 0.133 & 3.883 & 3.617 & Usually \\
\hline \multicolumn{6}{|c|}{ Selection based on personal relations } \\
\hline 2.75 & 0.754 & 0.151 & 2.901 & 2.599 & Sometimes / Rarely \\
\hline \multicolumn{6}{|c|}{ Selection from Turkey } \\
\hline 3.56 & 0.708 & 0.142 & 3.702 & 3.418 & Usually \\
\hline \multicolumn{6}{|c|}{ Selection from host country } \\
\hline 3.31 & 0.685 & 0.137 & 3.447 & 3.173 & Usually / Sometimes \\
\hline \multicolumn{6}{|c|}{ Selection from other countries } \\
\hline 2.06 & 0.558 & 0.112 & 2.172 & 1.948 & Rarely \\
\hline
\end{tabular}




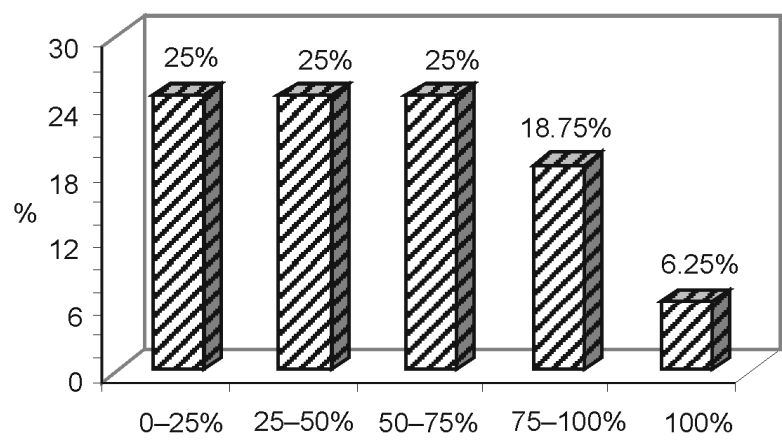

Fig. 2. Amount of work transferred to subcontractors in a foreign project

Construction projects involve various trade disciplines. A great number of different operations are required in construction projects, and hundreds of work items can easily be subcontracted in most construction projects. As shown in Fig. 3, there is a variable dispersion in the numbers of subcontractors. Although the project type in which the main contractor specializes has an effect on the usage of subcontractors, it is evident that many subcontractors are employed in foreign projects in normal conditions. Therefore, subcontractor coordination can have a large influence over the project success in particular, and firms increasing the number of subcontractors can have trouble in controlling the coordination process.

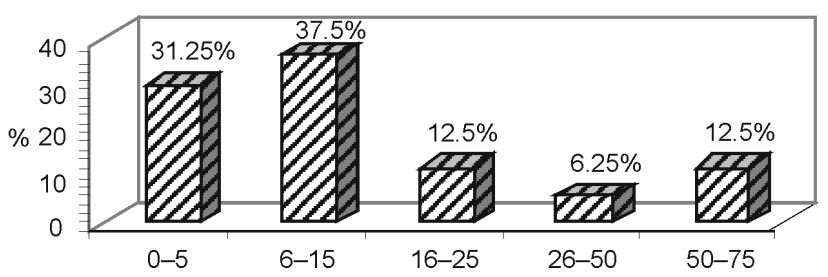

Fig. 3. Maximum number of subcontractors in a foreign project

Subcontractors in foreign projects are mostly chosen by 'a few top managers' (56.25\%), as shown in Fig. 4. Besides this selection method, the number of main contractors performing the selection process by means of ' $a$ mixed group of technical and managerial personnel' who should be the real decision-makers is low (37.5\%). The decisions made this way are finalized by the approval of a company's top management. The percentage of firms using 'one-man decisions' is very low $(6.25 \%)$, which is a positive finding of the survey.

The survey indicated that the main contractors' decision-makers 'usually' or 'sometimes' selected subcon- tractors based on their personal experience and judgment alone, without using any methodological or numerical approach (Table 2), which indicates a serious problem. Although $12.5 \%$ of main contracting companies 'never' make subcontractor selections based on this criterion, it is also a very negative finding that $18.75 \%$ 'always' choose subcontracting firms by this means.

Both main contractors and subcontractors tend to rely on personal relationships during the bidding process since they suppose that closer informal communication can reduce project-related risks to some extent. However, this is not a professional approach, and it may negatively affect project success. The main contractors 'sometimes' or 'rarely' act in this manner (Table 2). Although none of the surveyed main contractors 'always' used this criterion, there were no main contractors who 'never' used this method of choosing subcontractors.

Of the main contractors, $56.25 \%$ had prepared specifications or procedures concerning the subcontractor selection, while a large number of them (43.75\%) had made no effort in this regard. The procedures suggested for the selection process did not contain any detailed statement on the process and comprise only a few clauses that are composed of very general expressions without making any useful guidance. Similarly, $62.5 \%$ of main contractors had actual subcontractor short-lists classified according to the construction trades, while the remaining $37.5 \%$ did not. Although it is advantageous that main contractors have these short-lists, the mission of the lists cannot be fulfilled exactly due to a lack of the clear description of steps in the selection process.

Main contractors provided subcontracting services in international projects using two means. The first is 'competitive bidding', which was 'usually' or 'sometimes' used (Table 2). Of main contractors, 12.5\% 'always' used this method of employing subcontractors, while no main contractors 'never' used it. The second method of procuring subcontracting services was 'negotiation with only one subcontractor', and this was preferred less than 'competitive bidding'. Main contractors 'sometimes' or 'rarely' chose 'negotiation with only one subcontractor', and none of the main contractors 'always' employed this method (Table 2). The fact that no main contractor 'never' uses this method indicates that the main contractors work with specific subcontractors on a continuous basis in some trades. However, since main contractors prefer 'competitive bidding' to 'negotiation with only one subcontractor', a selection process is put into practice in general.

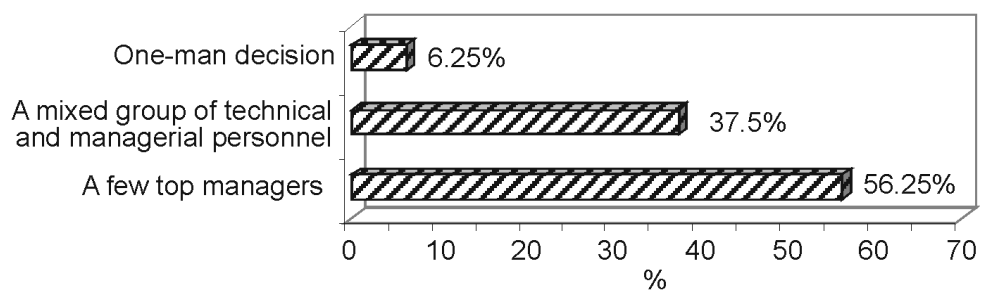

Fig. 4. Decision-maker of the subcontractor selection in a foreign project 
In foreign projects, previous project relationships and related satisfaction have significant impacts on the final decision because working with the same subcontractors on different projects develops strong personal relationships, harmonization, and mutual trust between the parties. In fact, it can be favorable to be based on this criterion since it pinpoints a continuous and long-term relationship between the main contractor and the subcontractor. The data stating that main contractors 'usually' choose subcontractors by means of this criterion (Table 2) are in agreement with the inference of 'negotiation with only one subcontractor'. No main contractor 'never' applied this method, which supports the same finding. However, an inadequate $6.25 \%$ 'always' used this method.

The main contractor's own resources, as well as profitability, usually govern the decision about what items to subcontract. Elazouni and Metwally (2000) put forth a decision-making support system that allowed contractors to simulate calculations for the best work item or the best proportion of the subcontracting. In construction bidding, subcontractors can be determined in one of the following time periods:

-Discussions occur between the main contractor and subcontractor before the main contract bid, and the subcontract becomes valid only when the main contract is awarded to the main contractor. In this method, the proposal cost is either unchanged or reduced according to the main contractor's discount rate in the main contract. In another case, proposals of subcontractors are taken to use in the main tender, and the selection decision is made after the main tender. However, this process is not valid for the projects in which the owner stipulates that all the subcontractors should be determined before the main tender. Some main contracts may even contain subcontract conditions.

- Subcontractors are awarded after the main contract tender or after the project start. However, it is better not to use this method in order to make a more robust decision since subcontractors should be chosen as early as possible within the procurement process to estimate activity inputs accurately and to overcome the adaptation period more quickly.

For foreign projects, it was discovered that main contractors mostly made the selection after the project's start (Table 2). Of them, 6.25\% 'always' used this method, and there was not any main contractor who 'never' used it. Choosing subcontractors between the main tender and the project's start is less used in practice than deciding after the project's start. Main contractors 'sometimes' selected subcontractors in this period (Table 2). No main contractors 'never' or 'always' employed subcontractors in this period. Although the real timing of the selection is before the main tender, it is less preferred when compared with the other time periods. As can be seen from Table 2, the selection is 'sometimes' made before the main tender. In addition, no main contractors 'never' or 'always' selected subcontractors in this period.
Many believe that the bid evaluation system, concentrating solely on the bid price, is a major cause of project delivery problems. The competitive low-bid procurement process can produce poor quality work, adversarial working conditions, a high incidence of subcontractor-generated change orders, claims, extensive delays in the planned work schedule, increased number of litigations, cost overruns, or perhaps all of these. The lowest bid does not necessarily produce the most economical end results or rational value; rather, it may lead to greater costs and involve high-risk exposure of the contractor in the long term. This means that the lowest tender received may not represent the best 'value for money' or the lowest possible price to the contractor. Although price focused low bid selections suggest monetary savings, they do not reflect the 'true/optimum cost' of the project and may result in a 'false economy'. Therefore, targeting the best bid price goals in any subcontractor selection exercise requires much more than a narrow focus on the economical aspects alone, and subcontracts should be awarded based on the best possible combination of a variety of quantitative and qualitative criteria. Although main contractors normally seek a low price, decision criteria should be reasonably reconciled. Furthermore, the specific capability cannot be generalized and quantified in the bid price only. Contractors may be unable to differentiate high-quality from low-quality subcontractors due to the single criterion selection because the statement of work in a subcontractor's proposal may be far different from what the subcontractor will actually do. Some subcontracting firms, especially those first entering into the market or faced with a shortage of work, may be prepared to submit suicidal bids to capture work opportunities, and they may hope to recoup any financial shortfall by adopting a confrontational 'claims oriented position' or cutting costs. The straightforward selection of a subcontractor on price alone is based on the assumptions that the specification used in the subcontract clearly defines the product that will be delivered by the subcontractor, that all subcontractors are the same, and that they will deliver similar quality output in all circumstances. Clearly, this is unlikely to be true in general practice. However, where contracts have been effectively designed and implemented, 'underbidding' need not be a problem. As shown in Table 2, main contractors in international construction projects 'sometimes' chose subcontractors based on the cost criterion. It is also a positive finding that none of them 'always' take into account the proposal cost alone. However, the fact that only $6.25 \%$ of the surveyed firms marked the 'never' option is a very negative finding. Although main contractors 'sometimes' evaluate the bid price as a unique selection criterion in foreign projects, they 'sometimes' or 'rarely' pick the lowest tender (Table 2). The statistical data showing that no main contractors 'always' chose the lowest bid, and that $25 \%$ of main contractors 'never' attach importance to this criterion are very positive indicators.

In foreign projects, subcontractors can be chosen from three potential markets. Mostly, Turkish subcontractors were chosen (Table 2). Main contractors 'usually' 
preferred Turkish firms since they know and can better communicate with subcontractors of the home country when compared with other subcontracting resources. No main contractors 'never' used Turkish subcontractors, while only $6.25 \%$ of main contractors 'always' employed this resource. Another subcontracting resource is made up of firms from the host country. Finding competent domestic subcontractors with a good supply chain in terms of resources is logistically critical to meet foreign contractors' obligations with the client for international construction. Foreign main contractors usually employ domestic subcontractors or large domestic contractors as subcontractors to reduce the adverse effects of resource mobilization, i.e., its procurement and high cost. However, foreign subcontractors have to evaluate mobilization and demobilization items. A local subcontractor has an established business relationship with local suppliers, allowing him to obtain certain discounts on purchased materials and timely deliveries. A domestic subcontractor also has better understanding and knowledge of the local working conditions, and he enhances the familiarity of the main contractor with the local market. When the domestic construction market has an undeveloped nature, loss of local firms and resources becomes a serious disadvantage for the main contractor. In addition, one of the most important objectives of the government in a developing country is to increase national participation in a public project. Therefore, a public-sector client in a host country generally recommends eligible domestic subcontractors to an international contractor for technology transfer. As can be seen in Table 2, although domestic firms were chosen less often than Turkish subcontractors, they were 'usually' or 'sometimes' used. However, no main contractors 'always' employed this type of resource due to its low productivity, and none 'never' utilized this resource's advantages. The last subcontracting resource is composed of firms from countries other than Turkey and the host country. These are the least used subcontractor type, and they were 'rarely' chosen by Turkish main contractors (Table 2). This may be because there is no special reason that requires using these subcontractors. Furthermore, it can also be supposed that serious factors such as communication difficulties and misunderstandings may have adverse effects on the relationship with these subcontractors. Of main contractors, $12.5 \%$ 'never' used this type of the subcontracting resource, and it was 'always' awarded by none of the main contractors.

\section{Discussion and results}

In international construction projects, Turkish main contractors often use subcontractors. Some main contractors regularly employ them, while some do not work with subcontractors. A very limited number of main contractors transfer the entire project to subcontractors. As a result, although subcontracting is not a unique element of foreign projects, Turkish main contractors frequently employ subcontractors.

In general, a few top managers in the main contracting firms select potential subcontractors. In some main contractors, a mixed group of technical and managerial personnel makes the final subcontracting decisions. Decisions made by single individuals are very rare. Decisionmakers frequently choose subcontractors based on their own experience without using any evaluation technique. Very few main contractors do not use such a selection process, and some of them regularly select subcontractors in this manner. The personal relationship between the subcontractor and the top managers of the main contractor is occasionally considered as a unique selection criterion. Although no main contractors continuously award subcontracts by this way, there is also not any main contractor who does not follow this method. More than half of the main contractors have procedures for the selection process despite the unqualified nature of these internal specifications. In this respect, it appears that professionalization, including task-sharing and responsibility-giving philosophies, is still developing in Turkish contracting companies.

Main contractors mostly select their subcontractors by competitive bidding. Although only a small number of them continuously use this method, there are no main contractors who do not employ subcontractors by this method. Negotiation with a specific subcontractor is a less used bidding system. Although no main contractor applies this system to every project, each main contractor has applied it in at least a few projects to date. In addition, main contractors are generally willing to work with previously known subcontractors who showed superior performance, but very few of them choose subcontractors by this way on a continuous basis. However, all main contractors use this method at least some of the time. Furthermore, many main contractors have updated subcontractor lists including all the construction trades. In this context, a considerable portion of the main contractors have generally determined specific subcontractors in some trades in order to have continuous working relationships, which change with the geographical location, type, and scale of projects. It is, however, evident that they do not perceive this approach as a strategic issue and do not support the selection process by means of related models.

In general, main contractors choose the required subcontractors after the project's start. The portion of main contractors following this way in every project is very low, although no main contractors never conform to this time period. Main contractors occasionally select subcontractors between the main tender and the project's start. No main contractors regularly do this, and none never use this method. Subcontractor selections are seldom done before the main tender. No main contractors regularly or never choose subcontractors in this period. According to these findings, it appears that the time period between the main tender and the project's start is mostly not suitable for choosing subcontractors because the detailed project planning should be carried out before the main tender. Accordingly, it is clear that main contractors do not recognize the importance of construction planning.

Subcontractor selection based on bid price does not occur frequently. Although none of the main contractors regularly make a selection decision based on the cost 
criterion, only a few main contractors do not apply this method. Similarly, the selection of the subcontractor offering the lowest project cost is an uncommon practice. None of the main contractors continuously choose subcontractors in this manner, and many main contractors do not consider this criterion alone. The main contractors are generally conscious in this respect. Nevertheless, some of main contractors do not understand that a cost-focused bidding strategy is likely to result in permanent complications during a construction project.

In international projects, main contractors mostly select Turkish subcontractors, and no main contractors do not use Turkish subcontractors. However, very few main contractors use this resource on a continuous basis. Firms from the host country are selected less often than Turkish subcontractors. No main contractors regularly employ or do not use this resource type. Subcontractors from other countries are very seldom employed by Turkish main contractors. Although none of these main contractors continuously use this resource, only a few of them do not employ this kind of subcontractor. Consequently, it can be claimed that main contracting firms in general share construction projects between Turkish subcontracting companies and those from the host country, and that they use the firms from other countries as a supplementary subcontracting resource.

\section{Conclusions}

In today's competitive business environment, subcontracting arrangements are an important practice in international construction projects. The subcontracting device has considerable importance to each portion of a project because using in-house resources is costlier than outsourcing. In this context, international subcontracting as a production strategy was examined in this study by means of a statistical analysis.

Subcontracting is an extensive tool, and it is used widely in the execution of projects in the international construction market. Firms from both Turkey and the host countries are often used in foreign projects, but subcontractors from other countries are employed only as an alternative resource. Main contractors do not generally make the decision on the subcontractor selection by means of an in-house group including technical and managerial staff. Although the majority of them frequently employ previously known subcontracting firms, they have neither systematic processes nor models in place in order to select the best alternative. In most cases, they are aware that awarding a construction subcontract to the lowest bidder, without considering other factors, can result in problems such as cost overruns, delays, and poor performance. In general, since they do not recognize the importance of project planning, the selection of subcontractors is generally performed either after the main tender or after the project's start.

Although Turkish main contracting firms have some serious drawbacks in the practice of subcontracting in the international arena, they gain some significant advantages by using this practice to maintain their current superior position. First, main contractors do not depend on sub- contracting alone, and they support construction activities with their own resources, including equipment and labor. This is because the main contractor's control of the overall quality of construction is vastly improved when he uses his own resources. In other words, when the employment is direct, the control will be more effective. By having direct control on work, the contractor may get a better quality job. Since the client and main contractor have very little control over who carries out the specialist work under a subcontract, there is a looser relationship between employer and employee in subcontracting. Main contractors also take great advantages of employing Turkish and/or domestic firms, working with previously known subcontracting companies, and not considering low price alone.

\section{Acknowledgements}

The authors gratefully acknowledge the numerous chairpersons, managers, and other technical/administrative staff of the surveyed companies for their generous collaboration and contributions. The authors also thank the financial supports provided by the Committee on Research Grants of Akdeniz University and Turkish Education Foundation.

\section{References}

Albino, V.; Garavelli, A. C. 1998. A neural network application to subcontractor rating in construction firms, International Journal of Project Management 16(1): 9-14. doi:10.1016/S0263-7863(97)00007-0

Araz, C.; Ozfirat, P. M.; Ozkarahan, I. 2007. An integrated multicriteria decision-making methodology for outsourcing management, Computers and Operations Research 34: 3738-3756. doi:10.1016/j.cor.2006.01.014

Arslan, G.; Kivrak, S.; Birgonul, M. T.; Dikmen, I. 2008. Improving sub-contractor selection process in construction projects: web-based sub-contractor evaluation system (WEBSES), Automation in Construction 17: 480-488. doi:10.1016/j.autcon.2007.08.004

Babbie, E. 2007. The practice of social research. 11th edn., Belmont: Wadsworth Publishing.

Banaitiene, N.; Banaitis, A. 2006. Analysis of criteria for contractors' qualification evaluation, Technological and Economic Development of Economy 12(4): 276-282.

Bevilacqua, M.; Ciarapica, F. E.; Giacchetta, G. 2006. A fuzzyQFD approach to supplier selection, Journal of Purchasing and Supply Management 12: 14-27. doi:10.1016/j.pursup.2006.02.001

Bevilacqua, M.; Petroni, A. 2002. From traditional purchasing to supplier management: a fuzzy logic-based approach to supplier selection, International Journal of Logistics: Research and Applications 5(3): 235-255.

Bottani, E.; Rizzi, A. 2008. An adapted multi-criteria approach to suppliers and products selection - An application oriented to lead-time reduction, International Journal of Production Economics 111(2): 763-781. doi:10.1016/j.ijpe.2007.03.012

Brauers, W. K. M.; Zavadskas, E. K.; Turskis, Z.; Vilutienė, T. 2008. Multi-objective contractor's ranking by applying the MOORA method, Journal of Business Economics and Management 9(4): 245-255.

doi:10.3846/1611-1699.2008.9.245-255 
Chan, F. T. S.; Kumar, N. 2007. Global supplier development considering risk factors using fuzzy extended AHP-based approach, Omega - International Journal of Management Science 35: 417-431. doi:10.1016/j.omega.2005.08.004

Chang, S. L.; Wang, R. C.; Wang, S. Y. 2006. Applying fuzzy linguistic quantifier to select supply chain partners at different phases of product life cycle, International Journal of Production Economics 100: 348-359. doi:10.1016/j.ijpe.2005.01.002

Chen, C. T.; Lin, C. T.; Huang, S. F. 2006. A fuzzy approach for supplier evaluation and selection in supply chain management, International Journal of Production Economics 102: 289-301. doi:10.1016/j.ijpe.2005.03.009

Chou, S. Y.; Chang, Y. H. 2008. A decision support system for supplier selection based on a strategy-aligned fuzzy SMART approach, Expert Systems with Applications 34(4): 2241-2253. doi:10.1016/j.eswa.2007.03.001

Curwin, J.; Slater, R. 1992. Quantitative methods for business decisions. 3rd edn. London: Chapman and Hall.

David, J. L.; Ronald, S. R. 1987. Marketing research. 7th edn. New Jersey: Prentice Hall.

DeBoer, L.; Labro, E.; Morlacchi, P. 2001. A review of methods supporting supplier selection, European Journal of Purchasing and Supply Management 7: 75-89. doi:10.1016/S0969-7012(00)00028-9

Dogan, I.; Sahin, U. 2003. Supplier selection using activitybased costing and fuzzy present-worth techniques, Logistics Information Management 16(6): 420-426. doi:10.1108/09576050310503394

Egemen, M.; Mohamed, A. N. 2005. Different approaches of clients and consultants to contractors' qualification and selection, Journal of Civil Engineering and Management 11(4): 267-276.

Elazouni, A. M.; Metwally, F. G. 2000. D-sub: decision support system for subcontracting construction works, Journal of Construction Engineering and Management 126(3): 191200. doi:10.1061/(ASCE)0733-9364(2000)126:3(191)

El-Sawalhi, N.; Eaton, D.; Rustom, R. 2007. Contractor prequalification model: state-of-the-art, International Journal of Project Management 25: 465-474. doi:10.1016/j.ijproman.2006.11.011

ENR (Engineering News-Record). 2008. Available from Internet: $<$ http://enr.construction.com/>.

Haq, A. N.; Kannan, G. 2007. A hybrid normalised multicriteria decision-making for the vendor selection in a supply chain model, International Journal of Management and Decision Making 8(5/6): 601-622. doi:10.1504/IJMDM.2007.013421

Ip, W. H.; Yung, K. L.; Wang, D. 2004. A branch and bound algorithm for sub-contractor selection in agile manufacturing environment, International Journal of Production Economics 87: 195-205. doi:10.1016/S0925-5273(03)00125-7

Isiklar, G.; Alptekin, E.; Buyukozkan, G. 2007. Application of a hybrid intelligent decision support model in logistics outsourcing, Computers and Operations Research 34: 37013714. doi:10.1016/j.cor.2006.01.011

Juan, Y.-K.; Perng, Y.-H.; Castro-Lacouture, D.; Lu, K.-Sh. 2009. Housing refurbishment contractors selection based on a hybrid fuzzy-QFD approach, Automation in Construction 18: 139-144. doi:10.1016/j.autcon.2008.06.001

Kagnicioglu, C. H. 2006. A fuzzy multiobjective programming approach for supplier selection in a supply chain, The Business Review 6(1): 107-115.
Kahraman, C.; Cebeci, U.; Ulukan, Z. 2003. Multi-criteria supplier selection using fuzzy AHP, Logistics Information Management 16(6): 382-394. doi:10.1108/09576050310503367

Kumaraswamy, M. M.; Matthews, J. D. 2000. Improved subcontractor selection employing partnering principles, Journal of Management in Engineering 16(3): 47-57. doi:10.1061/(ASCE)0742-597X(2000)16:3(47)

Kumar, M.; Vrat, P.; Shankar, R. 2006. A fuzzy programming approach for vendor selection problem in a supply chain, International Journal of Production Economics 101: 273285. doi:10.1016/j.ijpe.2005.01.005

Kwong, C. K.; Ip, W. H.; Chan, J. W. K. 2002. Combining scoring method and fuzzy expert systems approach to supplier assessment: a case study, Integrated Manufacturing Systems 13(7): 512-519. doi:10.1108/09576060210442671

Lopez, R. F. 2007. Strategic supplier selection in the addedvalue perspective: A CI approach, Information Sciences 177: 1169-1179. doi:10.1016/j.ins.2006.08.009

Okoroh, M. I.; Torrance, V. B. 1999. A model for subcontractor selection in refurbishment projects, Construction Management and Economics 17(3): 315-327. doi:10.1080/014461999371529

Singh, D.; Tiong, R. L. K. 2005. A fuzzy decision framework for contractor selection, Journal of Construction Engineering and Management 131(1): 62-70. doi:10.1061/(ASCE)0733-9364(2005)131:1(62)

Shash, A. A. 1998. Bidding practices of subcontractors in Colorado, Journal of Construction Engineering and Management 124(3): 219-225. doi:10.1061/(ASCE)0733-9364(1998)124:3(219)

Stinchcombe, A. L. 1959. Bureaucratic and craft administration of production: a comparative study, Administrative Science Quarterly 4(3): 168-187. doi:10.2307/2390676

TCA (Turkish Contractors Association). 2008. Available from Internet: $<$ http://www.tmb.org.tr/>.

Tserng, H. P.; Lin, P. H. 2002. An accelerated subcontracting and procuring model for construction projects, Automation in Construction 11: 105-125. doi:10.1016/S0926-5805(01)00056-5

Uher, T. E.; Runeson, G. 1984. Pre-tender and post-tender negotiations in Australia, Construction Management and Economics 2: 185-192.

Ulubeyli, S. 2008. Fuzzy multiple criteria decision making model for subcontractor selection in international construction projects. $\mathrm{PhD}$ Thesis, Istanbul University, Turkey.

Turskis, Z. 2008. Multi-attribute contractors ranking method by applying ordering of feasible alternatives of solutions in terms of preferability technique, Technological and Economic Development of Economy 14(2): 224-239. doi:10.3846/1392-8619.2008.14.224-239

Wang, H. S. 2008. Configuration change assessment: Genetic optimization approach with fuzzy multiple criteria for part supplier selection decisions, Expert Systems with Applications 34(2): 1541-1555. doi:10.1016/j.eswa.2007.01.020

Wang, H. S.; Che, Z. H. 2007. An integrated model for supplier selection decisions in configuration changes, Expert Systems with Applications 32(4): 1132-1140. doi:10.1016/j.eswa.2006.02.015

Zavadskas, E. K.; Turskis, Z.; Tamošaitienè, J. 2008. Contractor selection of construction in a competitive environment, 
Journal of Business Economics and Management 9(3): 181-187. doi:10.3846/1611-1699.2008.9.181-187

Zavadskas, E. K.; Turskis, Z.; Vilutienè, T. 2005. Simulation of multi-criteria selection of buildings' maintenance contractor using the game theory, Computer Modelling and New Technologies 9(2): 7-16.
Zavadskas, E. K.; Vilutienė, T. 2006. A multiple criteria evaluation of multi-family apartment block's maintenance contractors: I-Model for maintenance contractor evaluation and the determination of its selection criteria, Building and Environment 41(5): 621-632. doi:10.1016/j.buildenv.2005.02.019

\section{SUBRANGOVU PARINKIMO PRAKTIKA TARPTAUTINIŲ STATYBOS PROJEKTU VEIKLOJE}

\section{S. Ulubeyli, E. Manisali, A. Kazaz}

\section{S antrauka}

Straipsnyje pateikiami Turkijos generalinių rangovų praktiniai subrangovų parinkimo tyrimai, vykdant tarptautinius projektus. Akcentuojama dabartinè generalinio rangovo įmonių subrangos praktika, kuri sudaro ilgalaikę ir plačią rinkos dalị. Šiam tikslui buvo išsamiai apklausta iki 96 statybos i̇monių. Turkijos ir kitų vadovaujančiają poziciją užimančių šalių subrangovai teige, kad dažnai dirba su tarptautiniais projektais. Tačiau kitu šalių subrangos įmonès nedalyvauja toje veikloje. Generalinės rangovo įmonės paprastai pasirenka subrangovus pateikus pagrindinį pasiūlymą arba projekto pradžioje. Nors daugelis iš jų dažnai dirba su jau anksčiau žinomomis subrangos imonėmis ir pasirinkdamos geriausią subrangovą neatsižvelgia į pagrindinį rodiklị - žemiausią siūlomą kainą, nenaudoja sisteminių procesų ar modelių. Svarbiausia, kad generaliniai rangovai naudojasi ne tik subrangovų paslaugomis, bet ir vykdo veiklą, naudodamiesi jų turimais vidaus ištekliais. Taigi šis tyrimas bus ne tik potencialių tyrèjų žingsnis igyvendinti ir rasti įdomių panašumų bei skirtumų tarp šių šalių ir Turkijos, bet ir padèti rangovams stiprinti savo pozicijas bei didinti įsidarbinimo galimybes tarptautinèje rinkoje.

Reikšminiai žodžiai: subrangovai, parinkimas, užsienio projektai, statybos imonès.

Serdar ULUBEYLI. Assistant Professor of Construction Management Division in Civil Engineering Department at Zonguldak Karaelmas University, Turkey. His areas of academic research interests include subcontracting, international construction, labour productivity, total quality management, and project management. He has published many papers in various scientific journals and proceedings.

Ekrem MANISALI. Professor of Construction Management Division in Civil Engineering Department at Istanbul University, Turkey. His research interests include multiple criteria decision-making, construction management, fuzzy logic systems, and project management. He is the editor of many professional journals.

Aynur KAZAZ. Associate Professor of Construction Management Division in Civil Engineering Department at Akdeniz University, Turkey. Her areas of academic expertise include construction management, total quality management, labour productivity, project management, and construction economy. Author of many papers published in professional journals and conference proceedings. 